\title{
Evaluation of Student Training Implementation in MSK Course At Educational Technology, Universitas Negeri Padang: Perspektive Training Participants
}

\author{
Zuwirna $^{a}$, Fetri Yeni J ${ }^{\text {b }}$ Ulfia Rahmic \\ Educational Technology, Padang State University \\ Padang, Indonesia \\ Corresponding e-mail: a zuwirnawz@gmail.com
}

\begin{abstract}
The purpose of this study was to evaluate the training activities undertaken by the students of Educational Technology in the framework of the implementation of Training Systems Management courses. The evaluation is reviewed from the implementation process that has been done in the semester of January- June 2016. Research is quantitative descriptive, with the object of research is student's participation in training implementation. Overall implementation of training programs organized by the students of Education Technology has well done. Nevertheless, there are still improvements to be done, especially at the organizing committee. The organizing committee of each training is categorized well, while the training materials raised, the selected characteristics of the speakers, and the place of the training activities are considered very good. Therefore, for the implementation of training programs implemented through the course of Management System Management need to clarify the responsibilities of implementing organizations in organizing training programs and activities.
\end{abstract}

Keywords: $\quad$ evaluation of training, training systems management

\section{INTRODUCTION}

Training is one of the efforts undertaken to develop human resources because the improvement, development, and formation of human resources are done through Training, education, and training. Basically, training contains by elements of Training and education. Training can be develop the potential of the workforce to work more, and better on jobs that are held or will be held in the future. Training is often conducted as an effort to improve the performance of educational workers who are considered not able to carry out their work due to factors of development needs of the community in education. Descriptively, the potential workforce in education field may already meet the administrative requirements of its work, but the workers must actively follow or compensate for the development of education in accordance with the duties held or to be held. This shows that training can facilitate career development of trainees in order to get good performance results.

In this regard, students of educational technology program that will carry out its function as a learning developer, in charge of developing human resources, both at school and outside school. If training can develop human resources, then this domain becomes the realm of the professorship of Education Technology. Therefore, Educational Technology program study, making Training System Management as one of compulsory subject for the students of Educational Technology. In this course students are given insight into the basic concepts of Training, how to manage and organize training components such as organizers, instructors, participants, materials and other components that optimize a training activity. After the introduction of the concept, students design training activities and are given the opportunity to carry out the design.

The success of a training conducted by the Education Technology students is the success in conducting training, both at the local and national levels. Assessment of the success of this designed and implemented training program, one of which was assessed by the trainees themselves who had attended the training. Assessment given by the trainees is an assessment that has been determined by the category of assessment by each group that held the training. 
Based on Training System Management lecture activities in the previous semester and year, there are several problems that arise in the implementation of the student training plan. The problem consists of disparities between students about their participation in all activities (activities), commitment, discipline, cooperation, responsibility, individual ability, and group communication. Therefore, the researcher is interested to evaluate the implementation of the training conducted by the students of Education Technology Faculty of Educational Sciences Universitas Negeri Padang in the course of Training System Management (TSM).

Based on the phenomenon, the problem in this research is related to the elements of training, especially the students as the training provider. Students as organizers need to show their participation in all activities (activities), commitment, discipline, cooperation, responsibility, individual ability, and group communication. The purpose of this study is to evaluate the implementation process of training conducted by students of Education Technology in the implementation of Training System Management course. The evaluation is reviewed from the implementation process that has been done in semester of January to June 2016.

\section{METHOD}

This research used descriptive quantitative research. This descriptive research is considered relevant to know the process of implementation of training by Technology Education students' semester of January-June 2016. This research was conducted in Training System Management course in Education Technology Study Program Faculty of Education Universitas Negeri Padang. follows:

The stagers of this study are as

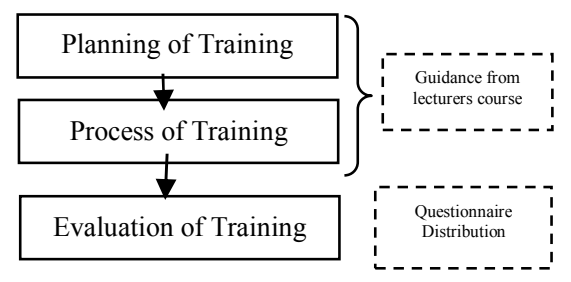

Figure 1. Procedure of Research

The research object is the process of training implementation by students on all training activities. The source of the data was obtained from questionnaires by participants who asked their participation to fill out questionnaires about materials, resource persons, and committees. Another source is the training implementation report by each training group. The research process is done as follows.

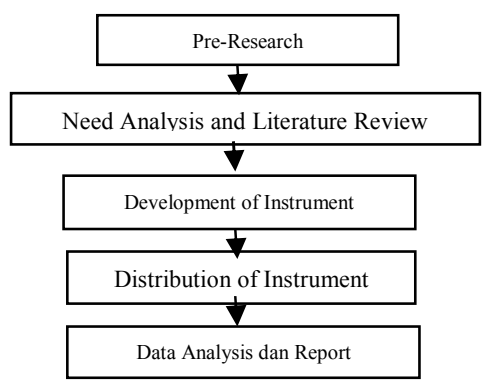

Figure 2. Process of Research

The technique of data analysis used in this research is descriptive analysis technique. The analysis is in the form of describing the result of questionnaire and training implementation report submitted by implementing of training group.

\section{RESULT}

1. Training of Writing Essay

Participants who register are as many as 201 people and come from Universitas Negeri Padang, STKIP PGRI and general participants. 131 participants came for participated in this training. The theme of this activity is "Toward Smart and Creative Students". The evaluation results of this training are presented in the following graph:

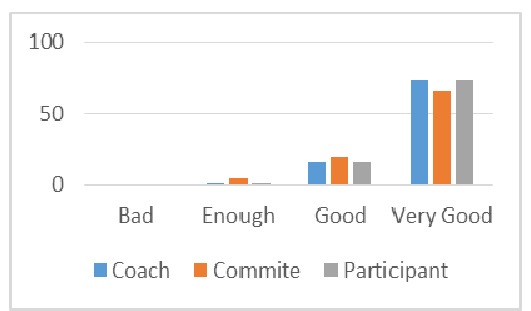

Figure 3. Training of Writing Essay Evaluation Result

From the graph presented above can be seen that the level of participants satisfaction to the dominant training in a very well position. After the calculation of the questionnaire filled by the trainees, it can be stated as follows:

a. 1 person of the participants rated the speakers quite well, 16 people are good 
and 73 people rate very well. None of the participants rated the less well.

b. 4 participants assessed the committee is good enough, 20 people judge good, and 66 people judge very well. While none of the participants judged less good.

c. 1 participant assessed the material given good enough, 16 people rate good and as many as 73 people rate very well. None of the participants rated the less well than the material presented.

2. Training of Photography

This activity is a training that gives some trick of being a good photographer in aiming an image by using DLSR camera with the theme "Sharpshooter with DLSR". The Training of Photography evaluation result is presented in graph 2 .

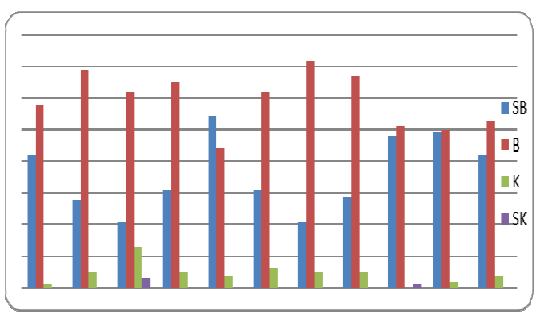

Based on the graph 2, there are three components presented, namely the committee, the speaker and the place/ training room. On the $\mathrm{X}$ axis on the graph is the questionnaire number of each component starting from 1 to 100. While on the $\mathrm{Y}$ axis is the value of each component obtained under the provisions in table 1 .

Overall evaluation results given by participants to each component are well. Based on the calculation result in table 1 obtained the average value for the committee of 78.95 , the average value of the speaker of 82.25 , while for the place / room average value of 85 . In this case can be categorized the average value of each training component Assessed are:

Table 1. Component of Training Assessment

\begin{tabular}{ccc}
\hline Component & Avarage & Information \\
Committee & 78.56 & Good \\
Presenters & 82.25 & Very Good \\
Place/Room & 85 & Very Good \\
\hline
\end{tabular}

In graph 2 we can see that overall the average value of each component is in the range of values 70 to 100 . It can be concluded that the Training of Photography Activities
Using DSLR Camera event is categorized "GOOD". This assessment is obtained based on the questionnaire given by the committee to participants attending photography training on May 21, 2016 at the Faculty of Education Auditorium.

Based on the above graph can be seen that each indicator has obtained different scores in each category that has been determined as follows:

a. Indicator 1: The participants who choose the category Very Good there are 42 people, good category there are 57 people, and the category is not good there 1 person.

b. Indicator 2: the participants who chose the categories Very Good there are 27 people, good category there are 68 people, and there are less good category 5 people.

c. Indicator 3: The participants who chose the categories Very Good there are 21 people, good category there are 63 people, and category less there are 13 people, and very less 3 people

d. D. Indicator 4: The participants who chose the categories Very Good there are 31 people, good category there are 65 people, and there are less good category 4 people.

e. E. Indicator 5: The participants who choose the categories Very Good there are 54 people, good category there are 44 people, and there are less good category 2 people.

f. F. Indicator 6: The participants who chose the categories Very Good there are 32 people, good category there are 63 people, and there are less good category 5 people.

g. G. Indicator 7: The participants who chose the Very Good category there are 22 people, good category there are 73 people, and the less good category there are 5 people.

h. H. Indicator 8: The participants who choose the categories Very Good there are 29 people, good category there are 66 people, and the category is not good there are 5 people.

i. I. Indicator 9: The participants who chose the categories Very Good there are 47 people, good category there are 52 people, and very less category there is 1 person.

j. J. Indicator 10: The participants who chose the categories Very Good there are 48 people, good category there are 
50 people, and bad category there are 2 people.

k. K. Indicator 11: The participants who chose the categories Very Good there are 43 people, good category there are 54 people, and there are less good category 3 people.

\section{Training of Journalistic}

This training activity is for students who want to enter the journalism world one of them in terms of covering and writing news with the theme "Building Student Creativity in Covering and Writing News".

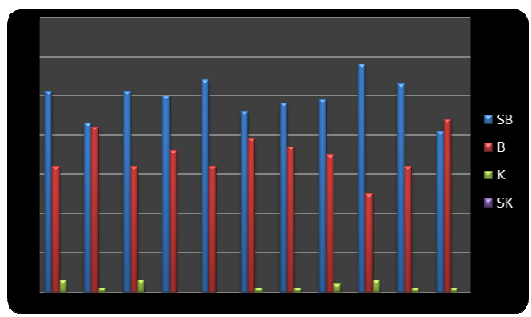

Figure 4. Graph of Evaluation Results on Basic Journalism Training

Based on the graph of questionnaire data analysis, it can be concluded the assessment categories of each indicator on the evaluation sheet of participants to the implementation of basic journalistic training as follows:

a. Assessment of the organizing committee

1) Service to trainees with respondents as many as 86 people obtained respondents who rate the category very good 51 people, good category 32 people, less 3 people.

2) Response to requests and complaints participants with respondents as many as 86 people obtained respondents who rate the category of very good 43 people, good category 42 people, less 1 person

3) Consistency of the committee on the training schedule with respondents as many as 86 people obtained respondents who rate the category of very good 51 people, good category 32 people, less 3 people

4) The responsibility of the committee on each task with respondents' as many as 86 people obtained respondents who rate the category very well 50 people, good category 36 people. b. Assessment of the presenters

1) Mastery of training materials with respondents as many as 86 people obtained respondents who rate the category very good 54 people, good category 32 people.

2) The use of language with respondents as many as 86 people obtained respondents who rate the category very good 46 people, good category 39 people, less 1 person.

3) Responses to the questions of trainees with respondents as many as 86 people obtained respondents who rate the category very good 48 people, good category 37 people, less 1 person.

4) Allocation of time when providing training with respondents as many as 86 people obtained respondents who rate with very good category 49 people, good category 35 people, less 2 people.

5) Control of media or tools used with respondents as many as 86 people obtained respondents who rate the category of very good 58 people, good category 25 people, less 3 people.

c. Assessment of the training room

1) Cleanliness of the room with respondents as many as 86 people obtained respondents who rate the category very good 52 people, good category 32 people, less 1 person.

2) Structuring the training room with respondents' as many as 86 people obtained respondents who rate very good category 41 people, good category 44 people, less 1 person.

So, it can be concluded that the implementation of basic journalism training has been done well.

4. Training of Public Speaking

Public Speaking or better known by the term of public speaking ability has become an important part in an organization and daily life, especially in lectures for students and in the learning and learning process for students and high school students / equal. Today's communication and speech skills can be likened to the heart that can enliven and mobilize all potential within the organization to achieve and realize ideal ideals. The role of communication is also very important in building the image, promotion and communication of an organization to people outside the organization. 
A communication practitioner in order to build the image must be able to master the various communication techniques and speaking skills. In order to realize such a reliable communication practitioner, the Curriculum and Education Technology Department of Education Faculty of Universitas Negeri Padang held Public Speaking training.

The theme of this activity is "Show Your Self and Be a Good Speaker". Can be seen from the diagram results recapitulation questionnaire each point above that each point has a percentage of $\geq 60 \%$. Where for the assessment indicator of implementation (points $1-4)$ the average percentage of this indicator is $73 \%$ for indicator ratings of pointers (points $5-8$ ) have an average of $87 \%$. While the benefit indicator for participants are $90 \%$.

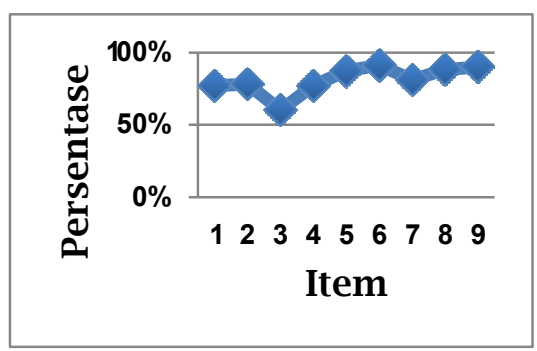

Judging from the success indicator that each indicator of each questionnaire: 1) the assessment indicator is $73 \%=\operatorname{good}, 2$ ) indicator of the rating of the speaker is $87 \%=$ excellent, and 3) the benefit indicator for the participants $90 \%=$ excellent.

5. Training of Visual Branding

From this Visual Branding Workshop we get some positive results, it is based on the result of questionnaires distributed to all workshop participants obtained the result of the percentage of workshop success as much as $78,54 \%$. In this visual branding workshop after the speaker delivered the material for approximately 1 hour, followed by the practice of making mood board (inspiration board) led by the speaker. Then the speakers assess the works result from the workshop participants' practice. Where, three participants with the best work based on the assessment of the presenters get a door prize that has been provided by the committee. Evaluation of this training is presented in the following graph

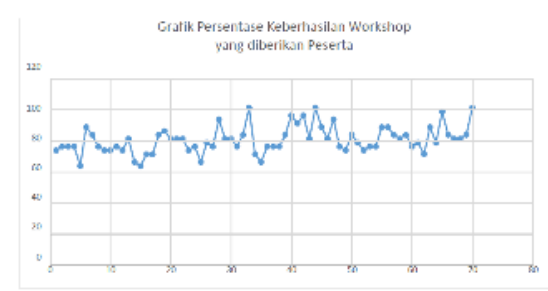

Based on predetermined criteria, from the above graphic results, the following results are obtained:

a) Services provided by the organizing committee of the workshop activities either, with a percentage of $78.21 \%$

b) The atmosphere during the workshop was considered good by the participants, it is based on percentage of $77.14 \%$

c) Timeliness in the workshop is considered less, with the percentage of $70 \%$

d) The strategy used by the presenters during the workshop is considered good with the percentage of $80 \%$

e) Speaker interaction with workshop participants assessed good with percentage $80,71 \%$

f) The tools / media used by the presenters during the workshop is being evaluated well with the percentage of $78.21 \%$

g) Clarity of material presented by the speakers is considered good with the percentage of $80.71 \%$

h) The master of the material presented at the workshop is considered very well, with the percentage of $86.42 \%$

i) Benefits earned by participants after the workshop is considered good with the percentage of 83.21

j) The material submitted ads to the participants' understanding and experience after the workshop is considered good with the percentage of $78.21 \%$.

\section{DISCUSSION}

Training System Management (TSM) is a compulsory subject in the Education Technology course at Faculty of Education in Universitas Negeri Padang. This course said to be compulsory because it is in accordance with the vision and mission of course study program that want to be realized, that is a) the vision of being a study program that can compete in South East Asia in producing 
educators and developers of learning technology in 2020 based on devotion to God Almighty B) the mission consists of 1) conducting education and learning to produce educators and learning technologies in the area of design, development, utilization, management and assessment of formal and non-formal education; 2) conducting research in technology in the areas of design, development, utilization, management and assessment of formal and non-formal education; 3) undertake technological devotion in the area of design, development, utilization, management and assessment of formal and non-formal education; 4) cooperate with related institutions in the field of learning technology development and develop service center and information technology education.

The desired outcomes after following TSM students have an insight into management, systems management, and Training system management and are able to design and implement in-door and outdoor training programs, and evaluate training programs and implementation. The purpose of the course refers and leads to the development of students' potential to manage the elements of training as a learning developer.

Lecture program provided to equip students to be able to manage a training activity by providing insight into a) understanding of management, system management and management of Training system, b) problem analysis and training objectives, c) training principles, d) development models Training programs, e) training design steps through needs analysis, situation analysis, objective formulation, material development, selection of training strategies and determination of learning resources, f) organizing personnel in the Training system, g) writing the design of training programs, $\mathrm{H}$ ) training evaluation system, i) implementation of training program and $\mathrm{j}$ ) report on implementation of training program implemented by the group.

The training activities in this TSM course have been conducted in January-July 2016 by appointing 5 (five) training programs, namely 1) writing training, 2) photography training, 3) journalistic training, 4) public speaking training, and 5) Visual branding training.

Overall the implementation of training programs organized by students of education technology program has been very good, but there are still improvements that must be done especially on the organizing committee. In the organizing committee of training is categorized well, whereas in the material presented, the characteristics of theater and the place of conducting the training activities are very good. Therefore, for the implementation of the next training program, there should be enhancement by the committee in the training program

\section{CONLUSIONS}

The research result on the implementation of training system management implemented by students in Education Technology Faculty of Education Universitas Negeri Padang in semester January-July 2016, proves that the training carried out in this course can be continued in the next academic year, given the results Obtained in this study showed satisfaction by the trainees and the satisfaction of the training committee in conducting the training. However, what needs to be improved in the next year's training program is at the organizing committee. This has been proven by the results of the above research that the respondents from the training participants stated that the material presented and the room where the training was conducted was very good, but the assessment for the organizing committee was only in the good category.

\section{REFERENCES}

[1] Arikunto, Suharsimi. (2009). Dasar-dasar Evaluasi Pendidikan. Jakarta: Bumi Aksara.

[2] Arikunto, Suharsimi dan Safruddin, Cepi. (2004). Evaluasi Program Pendidikan Pedoman Teoritis Praktis Bagi Mahasiswa dan Praktisi Pendidikan. Jakarta: Bumi Aksara.

[3] Hamalik, Oemar. (2007). Manajemen Pelatihan Ketenagakerjaan Pendekatan Terpadu Pengembangan Sumber Daya Manusia. Jakarta: Bumi Aksara.

[4] Sirnamora, Henry. (2006). Manajemen Sumber Daya Manusia. Yogyakarta: STIE YKPN.

[5] Tayibnapis, Farida Yusuf. (2008). Evaluasi Program dan Instrumen Evaluasi Untuk Program Pendidikan dan Penelitian. Jakarta: Rineka Cipta.

[6] Worthen, O. \& James, R. Sanders. (1987). Educational Evaluation: Alternative Approaches and Guidelines. New York: Longman Inc. 